\section{ANALYSIS OF UNSATURATED SOIL PARAMETERS AS SLOPE STABILITY MITIGATION}

Heriansyah Putraa*, Ahmad Rifa ib, Joko Sujonob, Alfira Silarukmia* Silarukmia

aFaculty of Engineering, Universitas Jambi, 36361 Jambi, Indonesia

bDepartment of Civil and Environmental Engineering, Gadjah Mada University, 55281 Yogyakarta, Indonesia
Article history

Received

10 March 2017

Received in revised form

18 July 2017

Accepted

6 September 2017

*Corresponding author heriansyah.putra@mail.ugm.ac.id

\section{Graphical Abstract}

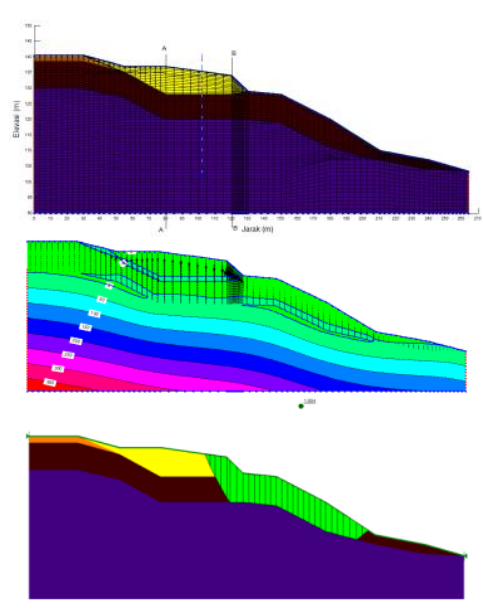

\begin{abstract}
The pore water pressure is the essential factor and plays a key role in the unsaturated soil parameters. Experimental works and numerical analysis were conducted to determine the critical condition of the slope stability due to the evolution of shear strength parameters. The effect of infiltration on the pore water pressure was evaluated. The filter paper method was conducted to obtain the matric suction in various degrees of saturation. The mechanical properties of the undisturbed samples were examined through triaxial and permeability test, respectively. WRPLOT View ${ }^{\top M}$ was adopted to assess the intensity and duration of the actual rainfall. The applicability of the psycho-empirical method in SOILVISION Database to fit Soil Water Characteristic Curve (SWCC) was studied. GEO-SLOPE was used to assess the evolution of the pore water pressure and its effect on the safety factor of the slope. The evolution of pore water pressure induced the infiltration influenced the shear strength parameters and reduced the safety factor. The reduction $20 \%$ of cohesion was obtained and hence, the safety factor decrease to 1.0. The infiltration at the beginning of the wet season is the most critical condition that increases the soil moisture significantly.
\end{abstract}

Keywords: Unsaturated soil, SWCC, Geo-Studio, slope stability, infiltration, rainfall

\subsection{INTRODUCTION}

In recent years, landslide induced rainfall infiltration has been studied extensively [1]-[16]. The infiltration of water increases the degree of saturation which is corresponding to the reduce the suction of the soil [17]. Infiltration caused water to absorb into the slope, and increase the weight of soil, decrease or loss of suction tension in the unsaturated zone, increase pore water pressure in the soil, internal erosion, and change in the mineral content of the soil mass on the slopes [7].

Rahardjo et al. [9] developed the slope stability analysis involve the unsaturated condition [9]. Characteristic of soil properties, flux boundary conditions, and field instrumentation is the main issue in this analysis. Field characteristics and laboratory experiments data are significant parameters in the analysis [3].

In this study, undisturbed samples from the site were used in experimental work. Physic and mechanical properties of the soil samples were examined in the laboratory. Triaxial and permeability test were conducted to analyze the shear strength parameters and coefficient of permeability on the saturation conditions, respectively. Filter paper method was utilized to evaluation the evolution of the matric suction in various degree of saturation.

WRPLOT View ${ }^{\top M}$ was adopted to assess the intensity and duration of the actual rainfall. The modification Green and Ampt infiltration model were adopted as the one-dimensional rainfall infiltration 
analysis. The applicability of the psycho-empirical method in SOILVISION Database to fit the soil-water characteristic curve (SWCC) was evaluated. GEOStudio was used to assess the evolution of the pore water pressure and its effect on the safety factor of the slope.

\subsection{METHODOLOGY}

\subsection{Material}

Undisturbed sand-clay samples from the KM 15.9 Kalibawang's main channel of Banjararum, Kalibawang, Kulonprogo, Yogyakarta were collected in February 2013 as the soil specimen in this work. Rainfall data during 1992 until 2012 from Pengelolaan Sumber Daya Air (PSDA) Yogyakarta was obtained as the main parameter in the infiltration analysis. Topography data from Kyi [18] was used in the numerical simulation.

\subsection{Soil Water Characteristic Curve}

The soil-water characteristic curve (SWCC) expresses the relationship between matric suction and/ gravimetric water content, volumetric water content or saturation. The SWCC is a fundamental soil characteristic, which is necessary to determine parameters of many processes in the soil such as infiltration, drainage, solute movement, and water availability for plants. It is also an important tool in the study of the strength and deformation of unsaturated soil. The shape of the SWCC is affected by many factors. Under the same confining pressure, the differences exist in the measured SWCC with different water contents during the compaction of soil mass [19][20]. The SWCC is significantly affected by the pore structure and particle size of the soil mass [20], [21]. The SWCC is also one of the main parameters in the model soil water and solute transport [22], [23].

In this study, filter paper method based on ASTM D5298-2003 was utilized to measure the evolution of the matric suction in various degree of saturation. The scheme of the filter paper method is depicted in Figure 1. Two blocks of the soil samples were prepared inside the PVC cylinder as the container. Three layers of filter paper were put between the soil samples. The sample was kept in the vacuum condition for 7 days to approach the equilibrium condition. The initial and final mass of the soil samples and filter paper were measured to know the water content of each case.

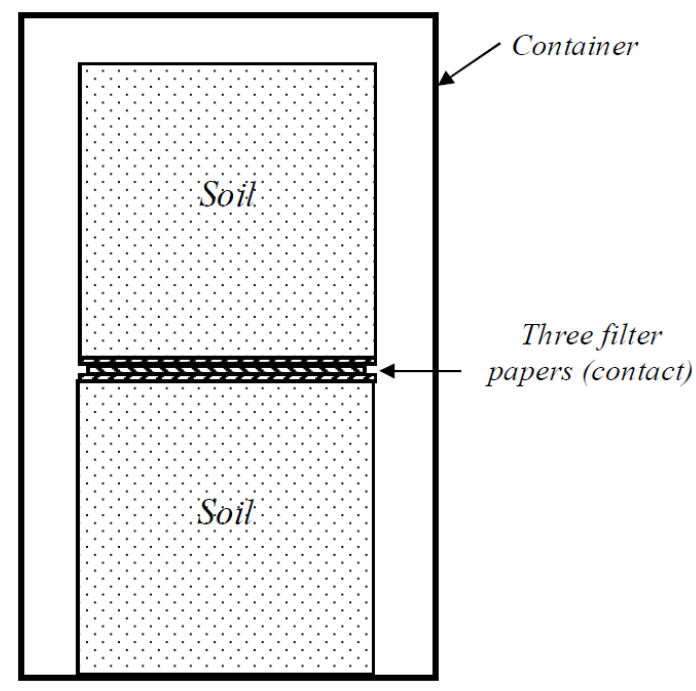

Figure 1 Scheme of filter paper method

A calibration curve in Figure 2 is used to obtain the matric suction from the water content of the filter paper (ASTM 5298-03).

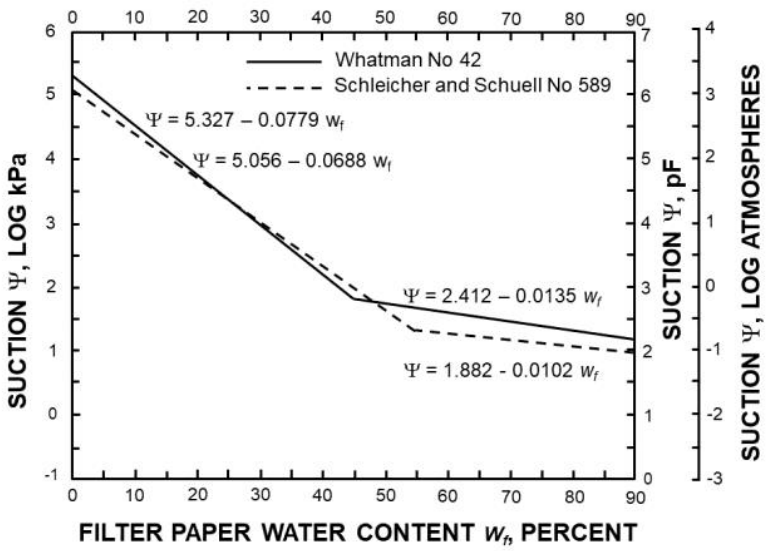

Figure 2 Calibration curves for the matric suction

\subsection{Green-ampt Infiltration Method}

The Green-Ampt model [24] was originally derived to predict the infiltration of ponded water into the underlying soil. The basic assumption underpinning the model is the infiltration causes the development of well-defined wetting front (see Figure 3). The soil above the wetting front is fully saturated, whilst below the wetting front, it remains at the initial (preinfiltration) water content. Gravity and matric suction effects control the movement of water in the saturated zone and the hydraulic gradient at the wetting front.

Infiltration analysis was accessed by the modified Green-Ampt equation. In this method, the boundary between the soil layers is defined. The wetting front in depth, $L$ will be affected by water after time, $\dagger$ [25]. The scheme of this method is depicted in Figure 3. 


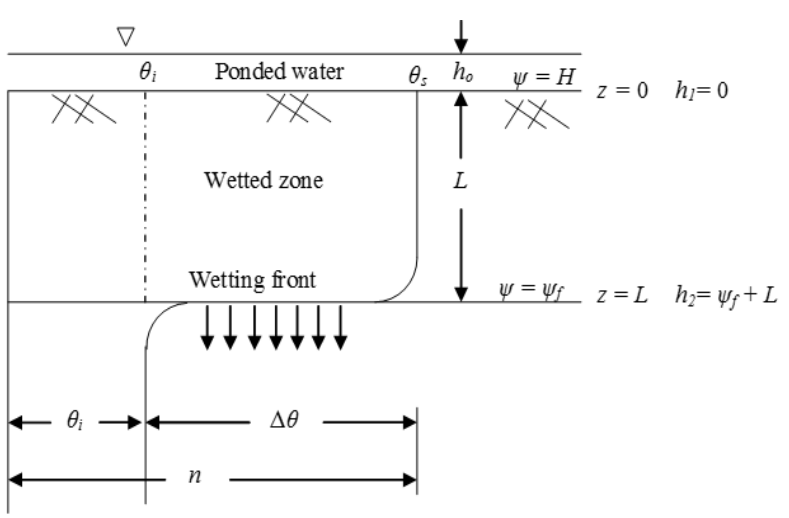

Figure 3 The scheme of Green-Ampt infiltration method

The controlling of the soil volume is used as the analysis parameters. The infiltrated water increases the saturation of the soil. Chen and Young [26] adopted this method to examine the infiltration in the slope. Equation (1) and (2) are presented to analyze the infiltration in slope.

$$
\begin{gathered}
f(t)=k_{\text {sat }}\left(\cos \beta+\frac{\psi \Delta \theta}{F}\right) \\
F=k_{\text {sat }} t+\frac{\psi \Delta \theta}{\cos \beta} \ln \left(1+\frac{F \cos \beta}{\psi \Delta \theta}\right) \\
\Delta \theta=\left(1-S_{e}\right) n_{e}
\end{gathered}
$$

Where: $F$ is the cumulative infiltration $(\mathrm{cm}), f(t)$ is the infiltration rate $(\mathrm{cm} / \mathrm{h})$ in time, $\Psi$ is the matric suction head, $k_{\text {sat }}$ is the coefficient of permeability in saturation condition.

In this work, the effective porosity and suction head were estimated from a Green-Ampt parameter which is presented by Rawls et al. [27] in Chow et al. [25]. Table 1 presents the slope and soil parameters for infiltration analysis.

Table 1 Parameters of infiltration analysis

\begin{tabular}{lccc}
\hline \multicolumn{1}{c}{ Parameters } & Silty clay & Mudstone & Clay \\
\hline Permeability, $\mathrm{k}_{\text {sat }}(\mathrm{cm} / \mathrm{h})$ & 0.0057 & 0.0086 & 0.0096 \\
Slope angle, $\beta(\circ)$ & 29 & 29 & 29 \\
Effective porosity & 0.423 & 0.385 & 0.385 \\
Suction head, $\Psi_{\mathrm{f}}(\mathrm{cm})$ & 29.22 & 31.63 & 31.63 \\
\hline
\end{tabular}

\subsection{Slope Stability}

Cohesion (c) and internal friction angle $(\varphi)$ are the main parameters in shear strength analysis [17]. The strength of soil is presented in equation (3)

$$
\tau=c+\sigma_{n} \tan \varphi
$$

$\tau$ is the shear strength $\left(\mathrm{kN} / \mathrm{m}^{2}\right), c$ is the cohesion $\left(\mathrm{kN} / \mathrm{m}^{2}\right)$, on is the normal stress $\left(\mathrm{kN} / \mathrm{m}^{2}\right)$, and $\varphi$ is the internal friction angle $\left({ }^{\circ}\right)$.
The pore pressure is reduced by the infiltration of water and decrease the slope stability. Ho and Fredlund [28] in [29] explain that the improving of the shear strength because the presence of the matric suction is defined as:

$$
c=c^{\prime}+\left(u_{a}-u_{w}\right) \tan \varphi^{b}
$$

Where $c^{\prime}$ is the effective cohesion $\left(\mathrm{kN} / \mathrm{m}^{2}\right),\left(\mathrm{Ua}_{\mathrm{a}} \mathrm{U}_{\mathrm{w}}\right)$ is the matric suction $\left(\mathrm{kN} / \mathrm{m}^{2}\right)$, and $\varphi^{\mathrm{b}}$ is the internal friction angle in unsaturated condition $(\mathrm{O})$. The shear strength of an unsaturated soil can be expressed in term of the independent stress state variable as follow [2].

$$
\tau=c^{\prime}+\left\{\left(\sigma-u_{a}\right)+\chi\left(u_{a}-u_{w}\right)\right\} \tan \varphi
$$

where $\left(\sigma-U_{a}\right)$ is normal stress in slip surface $\left(\mathrm{kN} / \mathrm{m}^{2}\right), \chi$ $\left(\varphi^{\mathrm{b}} / \varphi\right)$ is the unsaturated soil parameter.

\subsection{RESULTS AND DISCUSSION}

\subsection{Laboratory test}

The laboratory test results are present in Table 2. Three types of soil were examined in this work. The saturation condition was obtained in the initial state. The strength parameters and hydraulic conductivity were evaluated through the triaxial test and permeability test, respectively.

Table 2 Physic and mechanical properties of the soil samples

\begin{tabular}{lccc}
\hline \multicolumn{1}{c}{ Parameters } & $\begin{array}{c}\text { Silty } \\
\text { clay }\end{array}$ & Mudstone & Clay \\
\hline Specific gravity, $\mathrm{G}_{\mathrm{s}}(-)$ & 2.67 & 2.62 & 2.62 \\
Initial water content, $\omega(\%)$ & 52.29 & 54.89 & 51.09 \\
Initial saturation, $\mathrm{Sr}(\%)$ & 94.59 & 89.33 & 89.83 \\
Porosity, $\mathrm{n}(-)$ & 0.60 & 0.62 & 0.60 \\
Dry density, $\gamma_{\mathrm{d}}\left(\mathrm{g} / \mathrm{cm}^{3}\right)$ & 1.07 & 1.00 & 1.05 \\
Cohesion, $\mathrm{C}\left(\mathrm{kN} / \mathrm{m}^{2}\right)$ & 20.42 & 19.39 & 18.41 \\
Internal friction angle, $\varphi(\circ)$ & 2.89 & 3.82 & 3.82 \\
Permeability, $\mathrm{k}_{\text {sat }}(\mathrm{cm} / \mathrm{h})$ & 0.0057 & 0.0086 & 0.0096 \\
\hline
\end{tabular}

Filter paper method was conducted in various degree of saturation. Six conditions were obtained in this test. The drying method was used to reduce the water content for each condition. The saturation sample was drying 20 minutes at $60^{\circ}$ several times until the soil sample achieves the dry condition to obtain various saturations. Each condition after drying was used in the filter paper test. 3 samples for each condition is used to check the reproductively.

Table 3 presents the matric suction for each type of the soil sample in several conditions of the degree of saturation. Calibration curve in Figure 2 is used to obtain the matric suction. 
Table 3 Experiment result for the measured of matric suction

\begin{tabular}{ccccccc}
\hline \multirow{2}{*}{ Case } & \multicolumn{2}{c}{ Silty clay } & \multicolumn{2}{c}{ Mudstone } & \multicolumn{2}{c}{ Clay } \\
\cline { 2 - 7 } & $\begin{array}{c}\text { Sr } \\
\mathbf{( \% )}\end{array}$ & $\begin{array}{c}\text { Suction } \\
\mathbf{( k P a )}\end{array}$ & $\begin{array}{c}\text { Sr } \\
\mathbf{( \% )}\end{array}$ & $\begin{array}{c}\text { Suction } \\
\mathbf{( k P a )}\end{array}$ & $\begin{array}{c}\text { Sr } \\
\mathbf{( \% )}\end{array}$ & $\begin{array}{c}\text { Suction } \\
\mathbf{( k P a )}\end{array}$ \\
\hline A & 94.59 & 10.47 & 89.33 & 31.44 & 89.83 & 46.34 \\
B & 69.99 & 15.67 & 68.29 & 48.08 & 85.08 & 57.39 \\
C & 52.29 & 329.22 & 61.04 & 394.08 & 56.23 & 685.25 \\
D & 48.27 & 439.91 & 57.78 & 903.91 & 49.53 & 1357.72 \\
E & 44.41 & 505.02 & 53.41 & 1066.14 & 43.10 & 2614.56 \\
F & 31.82 & 995.65 & 37.01 & 3762.30 & 33.26 & 7138.75 \\
\hline
\end{tabular}

SOILVISION database was performed to fit the soilwater characteristic curve (SWCC) from the matric suction data. The fitting curves are depicted in Figure 4. The coefficient of determinant $\left(R^{2}\right)$ of 0.99 is achieved in the fitting of SWCC. This result confirmed that SOILVISION database applicable to solve the lack of data issue. SWCC is utilized as the data input in the pore water pressure analyze in SEEP/W.
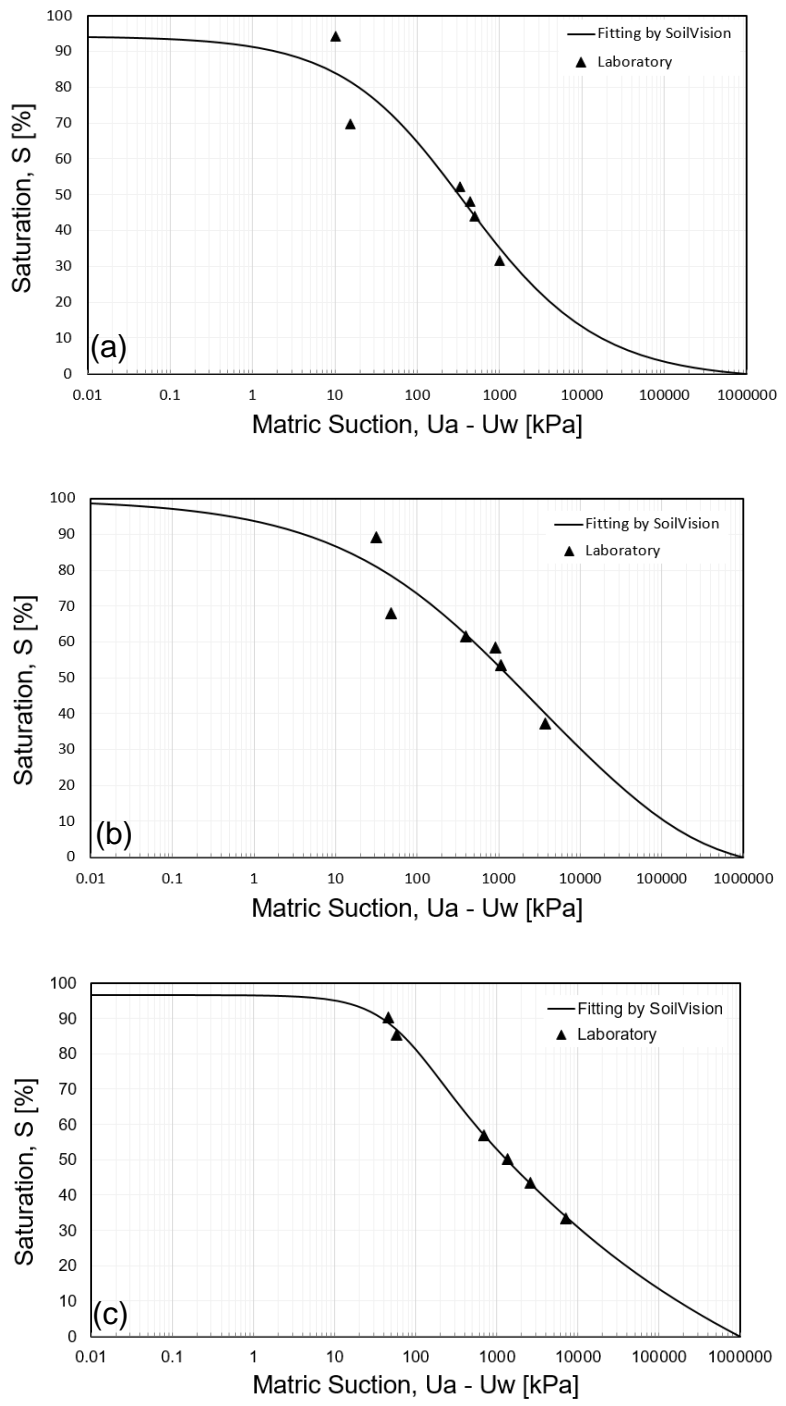

Figure 4 Soil Water Characteristic Curve (SWCC); (a) Silty clay; (b) Mudstone; (c) Clay

3.2 Rainfall and Infiltration Analysis
WRPLOT View'M is the best tools to find the characteristic of the wind, which also has two main parameters, velocity, and direction [30]. WRPLOT View ${ }^{\mathrm{TM}}$ was adopted to assess the intensity and duration of the actual rainfall. 20 years of hourly rainfall data from rainfall station in Kalibawang were used to obtain the monthly characteristic of the rainfall.

Figure 5 show the rainfall intensity and duration as the result of the WRPLOT View'M. In the WRPLOT $V_{\text {View }}^{\top M}$, the duration dominant is obtained from the resultant vector, and the intensity is taken from the dominant intensity in that duration.

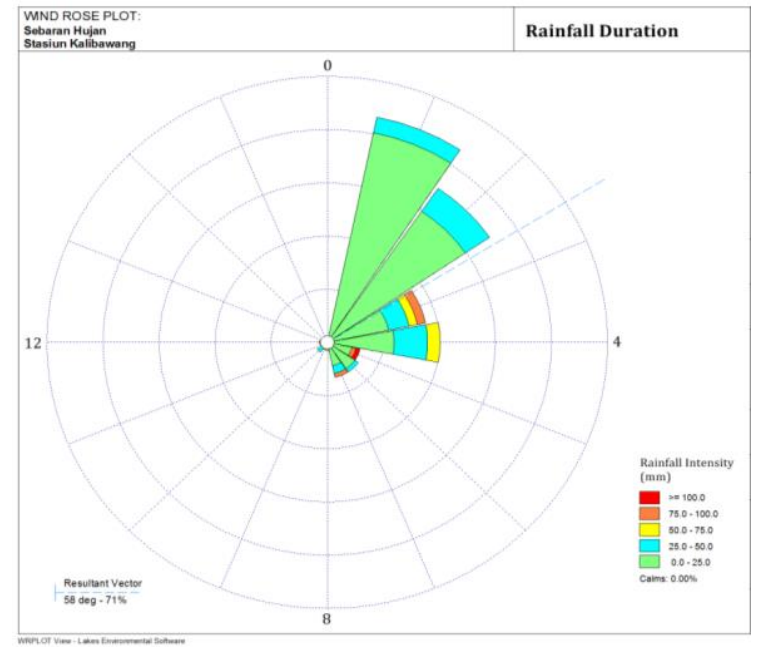

Figure 5 Output of the WRPLOT View ${ }^{\top M}$ on February

The summary of the monthly rainfall characteristics was present in Figure 6. The highest rainfall intensity is occurred on month $1^{\text {st }}$. The intensity decreased approached the lowest on the month $8^{\text {th }}$. Afterward, the intensity up back achieved the maximum. This result confirmed a couple of season in the location. The dry season obtained the decreasing of the intensity (i.e.: $5^{\text {th }}-8^{\text {th }}$ ) and the wet season considered to the enhancement of the intensity (i.e.: $9^{\text {th }}-4^{\text {th }}$ ).

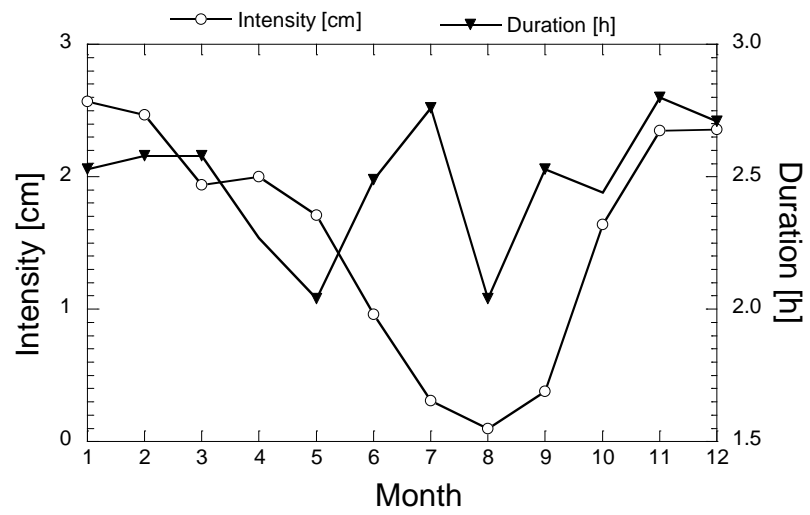

Figure 6 Rainfall characteristic 
Rainfall characteristics were used as the main parameters in the infiltration analysis in additional to the soil and slope parameters. The Green-Ampt infiltration method was conducted to obtain the rate in various soil types. The results of the infiltration analysis are presented in Figure 7.

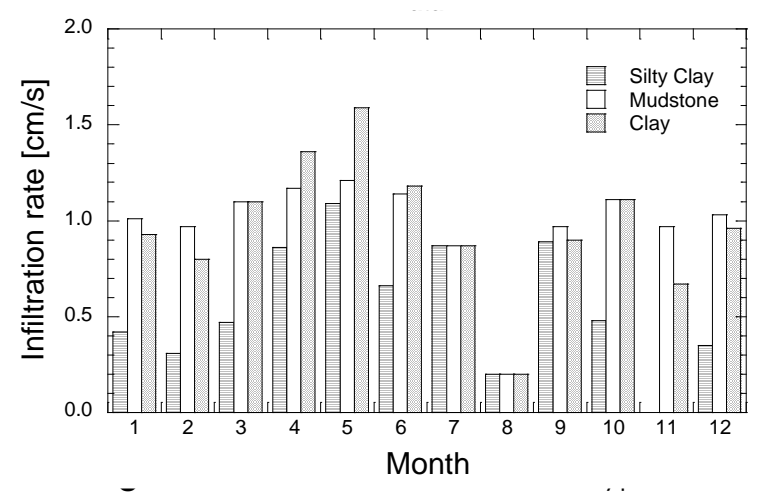

The highest rate of the infiltration achieved on the month $5^{\text {th }}$. As the rainfall analysis, the fifth month is the initial condition for the dry season. This result confirmed that the infiltration would achieve the highest rate in the low soil moisture.

\subsection{Evolution of the Pore Pressure}

SEEP/W as the part of GEO-Studio was utilized as the numerical simulation to obtain the evolution of the pore pressure induced the rainfall infiltration. The vertical evolution of pore pressure is showed in Figure 8.

In initial condition (without infiltration) the pore water pressure increases as the depth further increases as the line. In August (i.e., $8^{\text {th }}$ ), when the infiltration occurs, the water infiltrates up to the elevation of $126 \mathrm{~m}$. It is confirmed that rainfall for 1 month at the beginning of the wet season influenced the soil condition significantly. When the infiltration water applied for 2 months, water infiltrated up to the elevation of $119 \mathrm{~m}$ or achieved the water level. In this case, the soil already achieved the saturated condition.

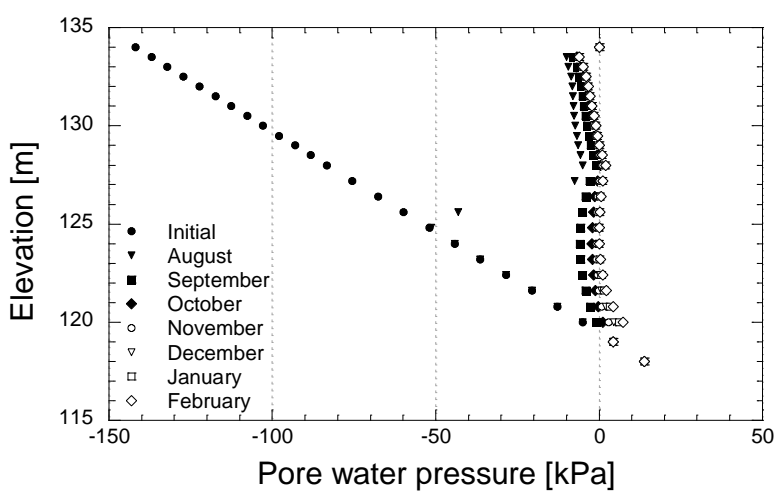

Figure $\mathbf{8}$ The evolution of the pore water pressure in depth
The evolution of pore water pressure is correspondence to the matric suction. Figure 9 Show the evolution of the matric suction as the effect of the infiltration. In the initial condition, the higher matric suction is obtained which is the dry condition. As the infiltration is applied, the matric suction was reduced significantly. Afterward, the matric suction is constant. It is confirmed that the infiltration of water in the dry condition is the most significant to the evolution of the matric suction.

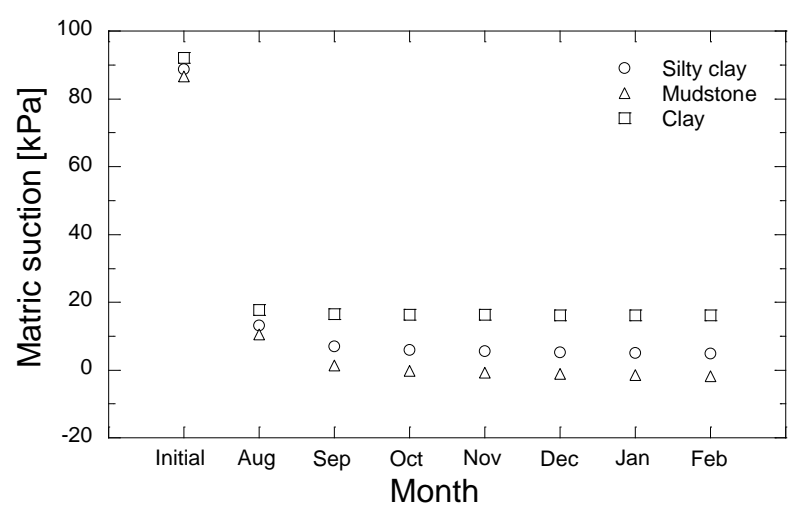

Figure 9 Evolution of matric suction by the month

\subsection{Effect of Infiltration to Safety Factor}

The effects of the decreasing of the matric suction induced the infiltration to the shear strength parameters were evaluated. The effect of the infiltration on the shear strength parameters is depicted in Figure 10. Cohesion reduced as the matric suction further decreased. The dry condition is the most significant affected by the infiltration of water. As the soil achieved the saturated condition, the cohesion approached the stable condition. In the same term is obtained in unsaturated internal friction angle $\left(\varphi^{\mathrm{b}}\right)$. The evolution of $\left(\varphi^{\mathrm{b}}\right)$ is inversely proportional as the cohesion.

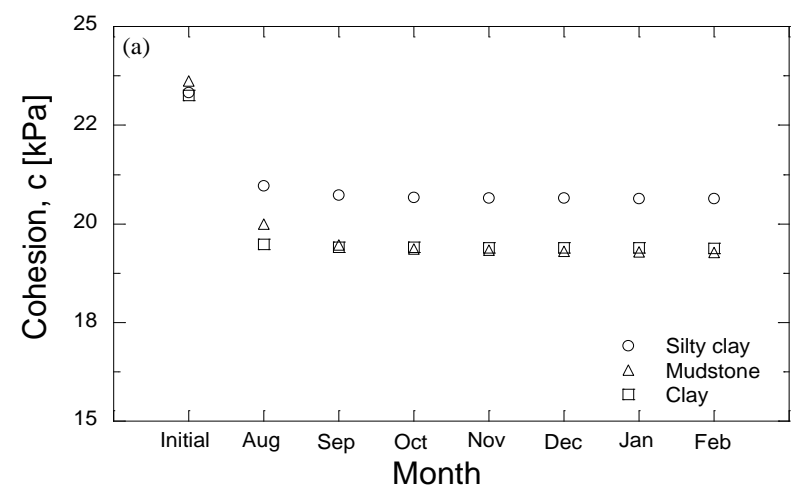




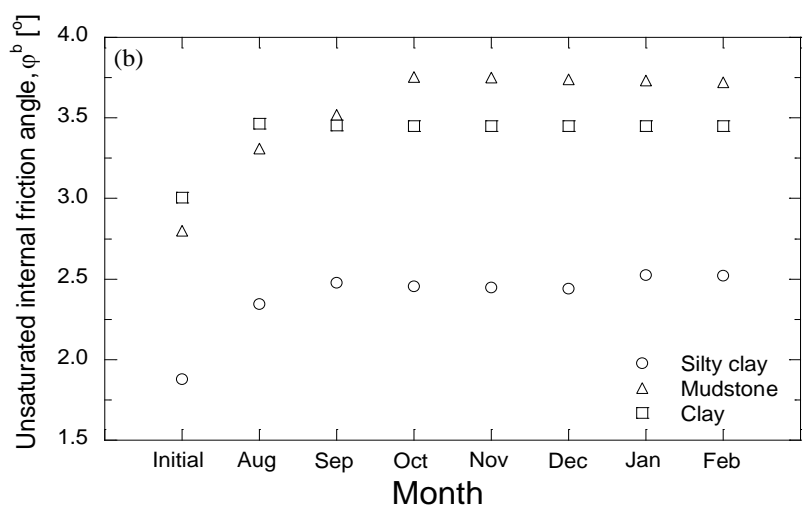

Figure 10 Evolution of the shear strength parameters by the month; (a) Cohesion; (b) internal friction angle

The evolution of shear strength parameters due to infiltration was utilized in SLOPE/W to analyze the slope stability. The evolution of safety factor is presented in Figure 11.

The evolution of safety factor by the month consider to the infiltration. This result considers to the effect of the infiltration to the matric suction. The reducing of the matric suction significantly reduced the safety factor of the slope. The critical condition is approached when the one-month infiltration is applied. The infiltration at the beginning of the wet season is the most consider as the slope stability mitigation.

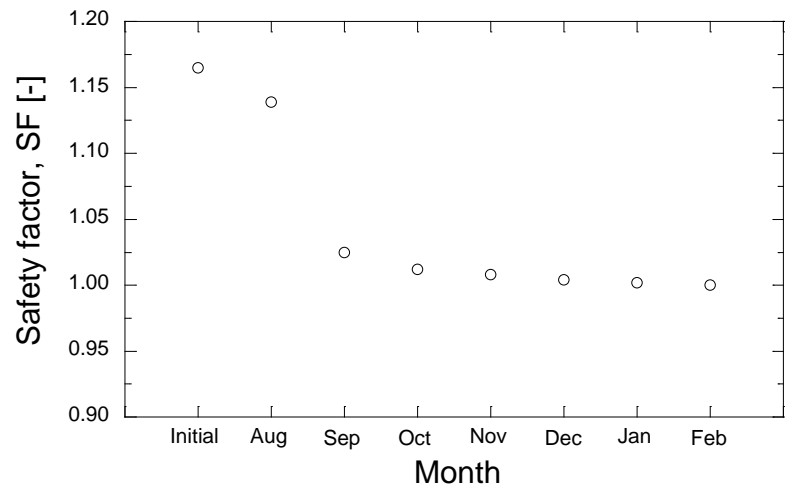

Figure 11 The evolution of safety factor

\subsection{CONCLUSION}

The effect of infiltration on the unsaturated soil parameters was evaluated. Laboratory experiments and numerical analysis are conducted to obtain the significant effect of the infiltration. SOILVISION databases are applicable to solve the lack of data issue.

The higher infiltration rate is obtained in the dry condition of the soil. The evolution of the pore water pressure significantly is occurred after 1 month of the infiltration was applied. The significant reducing of the matric suction happens on the initial infiltration.

The evolution of the matric suction influences to the shear strength parameters. As the matric suction increase significantly, the cohesion and internal friction angle further increase. As the result, the safety factor also decreases. The critical condition is approached on the initial infiltration is applied. The infiltration at the beginning of the wet season is the most consider as the slope stability mitigation.

\section{Acknowledgement}

This work has been supported by Beasiswa Unggulan (BU) DIKTI Scholarship, Indonesia. Their support is gratefully acknowledged.

\section{References}

[1] Lim, T. T., H. Rahardjo, M. F. Chang, and D. G. Fredlund. 1996. Effect of Rainfall on Matric Suctions in a Residual Soil Slope. Canadian Geotechnical Journal. 33(4): 618-628.

[2] Fredlund, D. G. and H. Rahardjo. 1993. Soil Mechanics for Unsaturated Soils. Canada: John Willey \& Sons, Inc.

[3] Muntohar, A. S. and H. J. Liao. 2010. Rainfall Infiltration: Infinite Slope Model for Landslides Triggering by Rainstorm. Natural Hazards. 54(3): 967-984.

[4] Muntohar, A. S., J. Ikhsan, and H. J. Liao. 2013. Influence of Rainfall Patterns on the Instability of Slopes. Civil Engineering Dimension. 15(2): 120-28.

[5] Muntohar, A. S., J. Ikhsan, and E. Soebowo. 2013. Mechanism of Rainfall Triggering Landslides in Kulonprogo, Indonesia. Geo-Congress 2013 @ A ASCE 2013. 452-461.

[6] Muntohar, A. S., Muhammad Uradi, and Andy Fourie. 2014. Development A Boundary of Rainfall-Induces the Stability of A Residuals Soils Slope in Northern Territory, Australia. Seminar Nasional Geoteknik 2014. Yogyakarta. 133-137.

[7] Karnawati, D. 2006. Pengaruh Kondisi Vegetasi Dan Geologi Terhadap Gerakan Tanah Dengan Pemicu Hujan. Media Teknik. 3: 12-22.

[8] Mustafa, M. R., M. H. Isa, R. B. Rezaur, and H. Rahardjo. 2015. Data-Driven Modelling for Pore Water Pressure Variation Responses to Rainfall. Sustainable Development. 1: 447-55.

[9] Rahardjo, H., E. C. Leong, and R. B. Rezaur. 2002. Studies of Rainfall-induced Slope Failures. Proceedings of the national seminar, Slope. April: 15-29.

[10] Wang, Gonghui, Akira Suemine, Gen Furuya, Masahiro Kaibori, and Kyoji Sassa. 2005. Rainstorm-Induced Landslides at Kisawa Village, Tokushima Prefecture, Japan, August 2004. Landslides. 2(3): 235-242.

[11] Haryanti, Sri, Kabul Basah Suryolelono, and Rachmad Jayadi. 2010. Analisis Pengaruh Karakteristik Hujan Terhadap Gerakan Lereng. Jurnal IImiah Semesta Teknika. 13(2): 105-15.

[12] Subiyanti, H. 2007. Analisa Kelongsoran Lereng Akibat Pengaruh Tekanan Air Pori Di Saluran Induk Kalibawang Kulonprogo. Gadjah Mada University. Yogyakarta.

[13] Pramusandi, Sony, Ahmad Rifa'i, and Kabul B. Suryolelono. 2015. Determination of Unsaturated Soil Properties and Slope Deformation Analysis Due to the Effect of Varies Rainfall. Procedia Engineering 125: 376382.

[14] Rifa'i, Ahmad. 2011. Effect of Matric Suction Changes on Unsaturated Soil Parameter Slope Stability Analiysis due to Rainfall. Seminar Nasional-1- BMTTSSI-Konteks. Sumatera Utara. G15-G23.

[15] Muntohar, A. S., Muhammad Suradi, and Andy Fourie. 2014. Effect of Rainfall Intensity and Initial Matric Suction on the Stability of Residuals Soils Slope Effect of Rainfall 
Intensity and Initial Matric Suction on the Stability of Residuals Soils Slope. Proceeding 18th Annual Conference on Geotechnical Engineering. Jakarta. 231236.

[16] Suradi, M., A. Fourie, C. Beckett, and O. Buzzi. 2014. Rainfall-Induced Landslides: Development of a Simple Screening Tool Based on Rainfall Data and Unsaturated Soil Mechanics Principles. Unsaturated Soils: Research \& Applications. (April 2016):1459-1465.

[17] Hardiyatmo, H. C. 2006. Tanah Longsor Dan Erosi, Kejadian Dan Penanganan. Yogyakarta: Gadjah Mada University Press.

[18] Kyi, Su Su. 2007. The Scoring System For Landslide Risk Microzonation and Mechanism of Weathered Tuff Layer In The Landslide Phenomena of Volcanis Area. Gadjah Mada University. Yogyakarta.

[19] Vanapalli, S. K., D. G. Fredlund, D. E. Putahi, and A. Clifton. 1996. The Model for Matric, Prediction of Shear Strength with Respect to Soil Suction. Canadian Geotechnical Journal. 33: 329-392.

[20] Gerard A, Miller, Khoury Charbel N, Muraleetharan Kanthasamy K, Liu Chunyang, and Kibbey Tohren C G. 2008. Effect of Soil Skeleton Deformation on Hysteretic Soil Water Characteristic Curve: Experiments and Simulations. Water Resources Research. 44(W00C06): 1-10.

[21] Indrawan, I. G. B., H. Rahardjo, and E. C. Leng. 2006. Effect of Coarse-Grained Materials on Properties of Residual Soil. Engineering Geology. 82(3): 154-64.
[22] Fu, Xiaoli, Mingan Shao, Dianqing Lu, and Huimin Wang. 2011. Soil Water Characteristic Curve Measurement without Bulk Density Changes and Its Applications in the Estimation of Soil Hydraulic Properties. Geoderma. 176178: 1-8.

[23] L'Heureux, J. S. 2005. Unsaturated Soils and Rainfall Induced Landslides. University of Oslo. Norwey.

[24] Green, W. H. and C. A. Ampt. 1911. Studies on Soil Physic: Flow of Air and Water through Soil. J. Agr. Sci. 4: 1-24.

[25] Chow, V. T, D. R Maidment, and L. W Mays. 1988. Applied Hydrology. Singapura: McGraw-Hill International Editions Civil Engineering Series.

[26] Chen, L. and M. H. Young. 2006. Green-Ampt Infiltration Model for Sloping Surface. Water Resources Research. 42(W07420): 1-9.

[27] Rawls, W. J., D. L. Brakensiek, and N. Miller. 1983. GreenAmpt Infiltration Parameters from Soil Data. Journal of Hydraulic Engineering. 109(1): 62-70.

[28] Ho, D. Y. F. and D. Fredlund. 1982. Increase in Strength due to Suction for Hongkong Soils. Geotechnical Conference on Engineering and Construction in Tropical and Residual Soils. ASCE. Honolulu, Hawai. 263-95

[29] Abramson, L. W., T. S. Lee, S. Sharma, and G. M. Boyce. 1995. Slope Stability and Stabilization Methods. New York: John Willey \& Sons, Inc.

[30] Triatmodjo, Bambang. 1996. Pelabuhan. Yogyakarta: Beta Offset. 